\title{
First evidence of the presence of genomic islands in Escherichia coli P4, a mammary pathogen frequently used to induce experimental mastitis
}

\author{
D. Dufour, ${ }^{\star}$ P. Germon, $†$ E. Brusseaux, ${ }^{*}$ Y. Le Roux, ${ }^{*}$ and A. Dary ${ }^{\star 1}$ \\ *URAFPA (Unité de Recherche sur l'Animal \& Fonctionalités des Produits Animaux), Equipe Protéolyse-Biofonctionnalité des Protéines \\ et des Peptides, Nancy-Université, Vandoeuvre-lès-Nancy, France \\ †INRA, UR1282 Infectiologie Animale et Santé Publique, F-37380 Nouzilly, France
}

\section{ABSTRACT}

Mastitis pathogens belonging to Escherichia coli species are often considered as environmental opportunistic pathogens that invade the udder and are rapidly killed by the immune system of cows. However, several studies have reported that some of these strains are able to persist in the udder for prolonged periods or to adhere and invade mammary epithelial cells, suggesting that they might possess some specific properties or genes that could be involved in their capacity to provoke mastitis. The aim of this work was to search for such specific genes in the $E$. coli strain $\mathrm{P} 4$, which was isolated from a case of severe mastitis and is often used to induce experimental mastitis. We established that this strain belongs to phylogenetic group A of the $E$. coli species, and that its core genome is very similar to that of the commensal nonpathogenic strain $E$. coli K-12 MG1655. Seventeen transfer RNA loci, known to be frequently associated with genomic islands, were screened and an altered structure was detected for 7 of them. The partial characterization of 5 of these loci (asnT, leuX, pheV, serU, and thr $W$ ) and the complete characterization of $1(\arg W)$ revealed the presence of genomic islands that differ from those already described in pathogenic or nonpathogenic E. coli strains.

Key words: Escherichia coli, bovine mastitis, phylogeny, genomic island

\section{INTRODUCTION}

Bovine mastitis is an economically important disease in dairy cattle worldwide (Bradley, 2002). It is defined as an inflammation of the mammary gland caused by a bacterial infection. Depending on the occurrence of various clinical signs, mastitis is referred to as clinical (elevated rectal temperature, dullness, loss of appetite, diarrhea, or a swollen and painful udder) or subclini-

Received May 17, 2010.

Accepted February 18, 2011.

${ }^{1}$ Corresponding author: Annie.Dary@scbiol.uhp-nancy.fr cal mastitis (Menzies et al., 2003). In both types of mastitis, milk production, as well as quality of milk, is affected. Production decreases considerably and milk quality declines strongly, particularly in regards to proteolysis of caseins - the major milk proteins (Michelutti et al., 1999). Among bacteria known to invade the udder and grow in this environment, Escherichia coli has been reported to be frequently responsible for clinical mastitis, and in rare cases, for fatal mastitis (Wenz et al., 2001; Burvenich et al., 2003; Shpigel et al., 2008).

Because of its ability to occupy different ecological niches, $E$. coli is considered to be a very versatile species (Bradley and Green, 2001; Touchon et al., 2009). Indeed, this species encompasses commensal and pathogenic isolates that can provoke different diseases: intestinal diseases ranging from mild diarrhea to severe colitis and dysentery, and extraintestinal diseases such as urinary tract infection or neonatal meningitis (Kaper et al., 2004). On the basis of their capacity to cause persistent or transient infection, mastitis pathogens have been divided into contagious or environmental pathogens, and, in this context, E. coli has been considered as an environmental pathogen (Nemeth et al., 1994). Several observations could account for such a classification. First, strains of E. coli isolated from mastitis cases belong to a large number of serotypes that are similar to those of fecal strains, whereas intestinal and extraintestinal pathogenic strains belong to a smaller number of serotypes (Burvenich et al., 2003). Second, no particular subset of genes involved in virulence and shared by all E. coli mastitis pathogens has been identified (Shpigel et al., 2008), virulence being defined here as the relative capacity to cause damage in a host (Casadevall and Pirofski, 2003). Numerous attempts have failed to identify, in various $E$. coli mastitis pathogens, genes encoding virulence factors known to be involved in the pathogenicity of intestinal or extraintestinal strains (Kaipainen et al., 2002; Lehtolainen et al., 2003; Ghanbarpour and Oswald, 2009). Finally, several studies have clearly showed that endotoxin or LPS is important during E. coli mastitis and that LPS constitutes a key molecule in the initiation of the inflam- 
mation. Thus, intramammary administration of LPS partially mimics the inflammatory reaction observed during E. coli mastitis (Burvenich et al., 2003). Several authors have proposed that $E$. coli mastitis pathogens constitute opportunistic invaders of the mammary gland, capable of inducing an inflammatory reaction and that most of them are rapidly eliminated by the innate host immune system. It was also proposed that the severity of a clinical $E$. coli mastitis, which varies among field cases from mild to fatal, depends more on factors related to the cow, such as the periparturient period, the early stage of lactation, the parity, or some hormonal and metabolic alterations, than on the type of $E$. coli strain that has induced mastitis (Burvenich et al., 2003).

However, several reports have shown that some strains of $E$. coli isolated from mastitis cases possess additional properties that could be important or improve their virulence. For example, Döpfer et al. (2000, 2001) and Dogan et al. (2006) noted that some of these strains display adhesion and invasion properties when placed in the presence of bovine mammary epithelial cells (primary and MAC-T cell cultures). Moreover, Bradley and Green $(2000,2001)$ have shown that some strains of $E$. coli are able to access the bovine mammary gland during the nonlactating period and then persist until the onset of lactation and cause clinical mastitis. Thus, all of these results suggest that at least the E. coli mastitis pathogens studied in these works may possess the capacity to survive and adapt to the mammary gland, where many antibacterial entities are present such as polymorphonuclear cells, immunoglobulins, lactoferrin, complement, lysozyme, lactoperoxidase, or cytokines (Sordillo et al., 1997; Rainard and Riollet, 2006).

It is clearly established that the gene pool of a bacterial species consists of a set of genes shared by all strains of the species and that constitute the core genome and by genes encoding accessory functions, such as specific metabolic properties or virulence factors. These latter genes can differ from strain to strain and confer specificity to different strains. They are often clustered in socalled genomic islands (GEI) that have been acquired by horizontal gene transfer events (Dobrindt et al., 2004). Genomic islands have been sought and widely characterized in intestinal and extraintestinal pathogenic E. coli strains (Hacker and Kaper, 2000), and in commensal strains (Grozdanov et al., 2004; Hejnova et al., 2006), but not yet in strains isolated from mastitis cases even though these strains may contain genes that could contribute to the development of mastitis.

The aim of this work was to initiate the genetic characterization of the prototypical strain E. coli P4 originally isolated from a case of severe bovine mastitis (Bramley, 1976). This strain is often used to induce experimental bovine mastitis and to study factors depending on the immune system of cows. It possesses the capacity to promote apoptosis and proliferation of bovine mammary cells (Long et al., 2001), and to adhere to or invade mammary gland epithelial cells in a murine model of mastitis (Gonen et al., 2007), suggesting that it could possess specific properties or genes that distinguish it from other commensal or pathogenic E. coli strains.

\section{MATERIALS AND METHODS}

\section{Bacterial Strains, Plasmids, and Culture Conditions}

Escherichia coli P4 (O32:H37, $\beta$-glucuronidase +, hemolysin -; Vangroenweghe et al., 2004) was provided by the Department of Comparative Physiology and Biometrics (C. Burvenich, Gent, Belgium). Escherichia coli O157:H7 EDL933 was used as a control, as well as Escherichia coli K-12, which was purchased from Institut Pasteur (Paris, France). Escherichia coli EPI100 (Epicentre, Madison, WI) was used as the recipient strain for the construction of a cosmid library of $E$. coli $\mathrm{P} 4$ genome, and the cosmid pWEB:Tnc (Epicentre) was used as vector.

The E. coli strains were grown in Luria-Bertani medium (Sambrook et al., 1989) with or without 1.5\% (wt/vol) Bacto Agar (Difco Laboratories, Detroit, MI) at $37^{\circ} \mathrm{C}$. Recombinant strains were grown in LuriaBertani medium supplemented with ampicillin (100 $\mu \mathrm{g} / \mathrm{mL}$; Euromedex, Souffelweyersheim, France). All strains were stored at $-70^{\circ} \mathrm{C}$ in Luria-Bertani medium supplemented with glycerol (20\% wt/vol).

\section{DNA Isolation, Electrophoresis, and Southern Hybridization}

Genomic DNA of E. coli P4, E. coli K-12 MG1655, and E. coli O157:H7 EDL933 was isolated as described previously (Leblond et al., 1996). For the construction of the cosmid library of $E$. coli $\mathrm{P} 4$ genome, genomic DNA of E. coli $\mathrm{P} 4$ was isolated as described previously (Sambrook et al., 1989). Recombinant cosmids were extracted by the alkaline lysis method (Sambrook et al., 1989). Purification of DNA fragments and extraction from agarose gel slices were performed with $\mathrm{Nu}-$ cleoSpin Extract II system (Macherey-Nagel, Hoerdt, France). The DNA fragments were separated on agarose gels according to Sambrook et al. (1989). Both 1-kb and 100-bp DNA ladders (Bio-Rad, Hercules, CA) were used as molecular weight markers. Southern blotting, prehybridization, and hybridization conditions were used as described previously by Demuyter et al. (1988). Labeling of probes and detection of specific hybrids 
were performed using the DIG DNA labeling and detection kit, under the conditions recommended by the supplier (Roche Molecular Biochemicals, Mannheim, Germany).

\section{Cosmid Library Construction and Screening}

Genomic DNA of E. coli P4 was partially digested with the restriction endonuclease Sau3AI (New England Biolabs, Beverly, MA) and ligated to the BamHI (New England Biolabs) digested cosmid vector pWEB:Tnc that had been pretreated with alkaline phosphatase (New England Biolabs). The recombinant cosmids were packed in phage heads with the Gigapack III XL system (Stratagene, Heidelberg, Germany), according to the instructions of the manufacturer, and used to infect E. coli EPI100. Recombinant cosmids containing the 6 identified altered transfer (t)RNA $(\arg W$, asp V, leuX, phe $V$, ser $U$, and $t h r W$ ) loci identified were first screened by PCR using 6 pairs of primers designed according to the nucleotide sequences of the region located downstream from these 6 tRNA loci and determined using an arbitrary PCR followed by a sequencing of the products. The PCR products obtained using these pairs of primers, and the E. coli $\mathrm{P} 4$ genomic DNA as template, were also used as probes in Southern hybridization experiments to confirm the identified recombinant cosmids. These probes were labeled and hybridized against EcoRI (New England Biolabs) restriction digest of the identified recombinant cosmids.

\section{PCR Primers}

All PCR primers used in this study (Table 1) were purchased from Eurogentec Society (Liège, Belgium). Primers enabling the partial amplification of the genes chuA, yjaA, and tspE4C2 were used to assign the strain $E$. coli $\mathrm{P} 4$ to 1 of the 4 phylogenetic groups of the $E$. coli species (Clermont et al., 2000) as follows: chuA positive and $y j a A$ positive $=$ group $\mathrm{B} 2 ;$ chuA positive and $y j a A$ negative $=$ group $\mathrm{D} ;$ chu $A$ negative and tspE $4 \mathrm{C} 2$ positive $=$ group $\mathrm{B} 1$; and $c h u A$ negative and tspE4C2 negative $=$ group $\mathrm{A}$.

Primers used for multilocus sequence typing (MLST) enabled the partial amplification of different housekeeping genes in the genome of E. coli K-12 MG1655: $a d k$ (adenylate kinase), gcl (glyoxylate carboligase), $g d h$ (glucose-6-phosphate dehydrogenase), $m d h$ (malate dehydrogenase), metA (homoserine transsuccinylase), ppk (polyphosphate kinase), aspC (aspartate aminotransferase), $\operatorname{clp} X$ (ATPase and specificity subunit of ClpX-ClpP ATP-dependent serine protease), fadD (acyl-CoA synthetase), $i c d A$ (isocitrate dehydrogenase), lysP (lysine transporter), aroE (shikimate dehydroge- nase), cstA (carbon starvation protein), cyaA (adenylate cyclase), dnaG (DNA primase), grpE (heat shock protein), mtlD (mannitol 1-phosphate dehydrogenase), mutS (methyl-directed mismatch repair protein), rpoS (sigma factor 38), and pgi (phosphoglucose isomerase) (Reid et al., 2002; Adiri et al., 2003). Additional primers were designed for the partial amplification of genes encoding the serine endoprotease $\operatorname{Do}(\operatorname{deg} Q)$ and the following putative proteases of unknown function in the genome of E. coli K-12 MG1655: ptrB (proteinase II), ycaL (putative protease), yhjS (putative protease), yaeL (zinc metallopeptidase), sms (probable ATP-dependent protease), yhjJ (predicted zinc-dependent peptidase), elaD (predicted enzyme), and $p m b A$ (predicted peptidase required for the maturation and secretion of the antibiotic peptide MccB17). The presence of the serum resistance factor traT was evaluated using primers already described by Kaipainen et al. (2002).

The primers of Dezfulian et al. (2003) were used to search potential GEI at the leuX, met $V$, selC, and thr $W$ tRNA loci, whereas the primers of Germon et al. (2007) were used to search for GEI at the asnT, asn $U V W$, asp $V$, gly $U$, phe $U$, phe $V$, ser $U$, ser $X$, and ser $W$ tRNA loci. For the $\arg U$ and $\arg W$ tRNA loci, GEI were searched using the primers designed from the E. coli K-12 MG1655 genome.

To amplify the first nucleotides of sequences located downstream of the interesting tRNA loci, arbitrary PCR consisting of 2 steps were used. The first corresponded to a PCR using genomic DNA of the strain as template, a first forward primer targeting the tRNA gene (argW1ter, asnT-F, aspV-F, leuX1, pheV3bis, serU3, and thrW1) and the degenerated reverse primers ARB1, ARB3, or ARB4. The second step corresponded to a PCR using an aliquot $(2 \mu \mathrm{L})$ of the products obtained during the first PCR as template, a second forward primer targeting a sequence of the same tRNA gene but located downstream from the region targeted with the first forward primer (argW-F, asnT3bis, aspV3, leuX3, pheV-F, serU-F, and thrW3), and the reverse primer ARB2.

Nine pairs of primers were designed to amplify the entire prophage-like element SpLE5 localized downstream from the leuX tRNA locus in E. coli O157:H7 Sakai genome (GenBank accession number: BA000007.2).

To screen recombinant cosmids containing the 6 identified altered tRNA loci identified $(\arg W, \operatorname{asn} T$, leuX, pheV, ser $U$, and thrW) 6 pairs of primers were designed according to the nucleotide sequences of the region located downstream from the interesting loci and determined by arbitrary PCR.

Finally, the entire genomic island located downstream from the $\arg W$ tRNA locus was amplified with the forward primer argW3bis, designed according to the first 
Table 1. Primers for PCR designed during this study

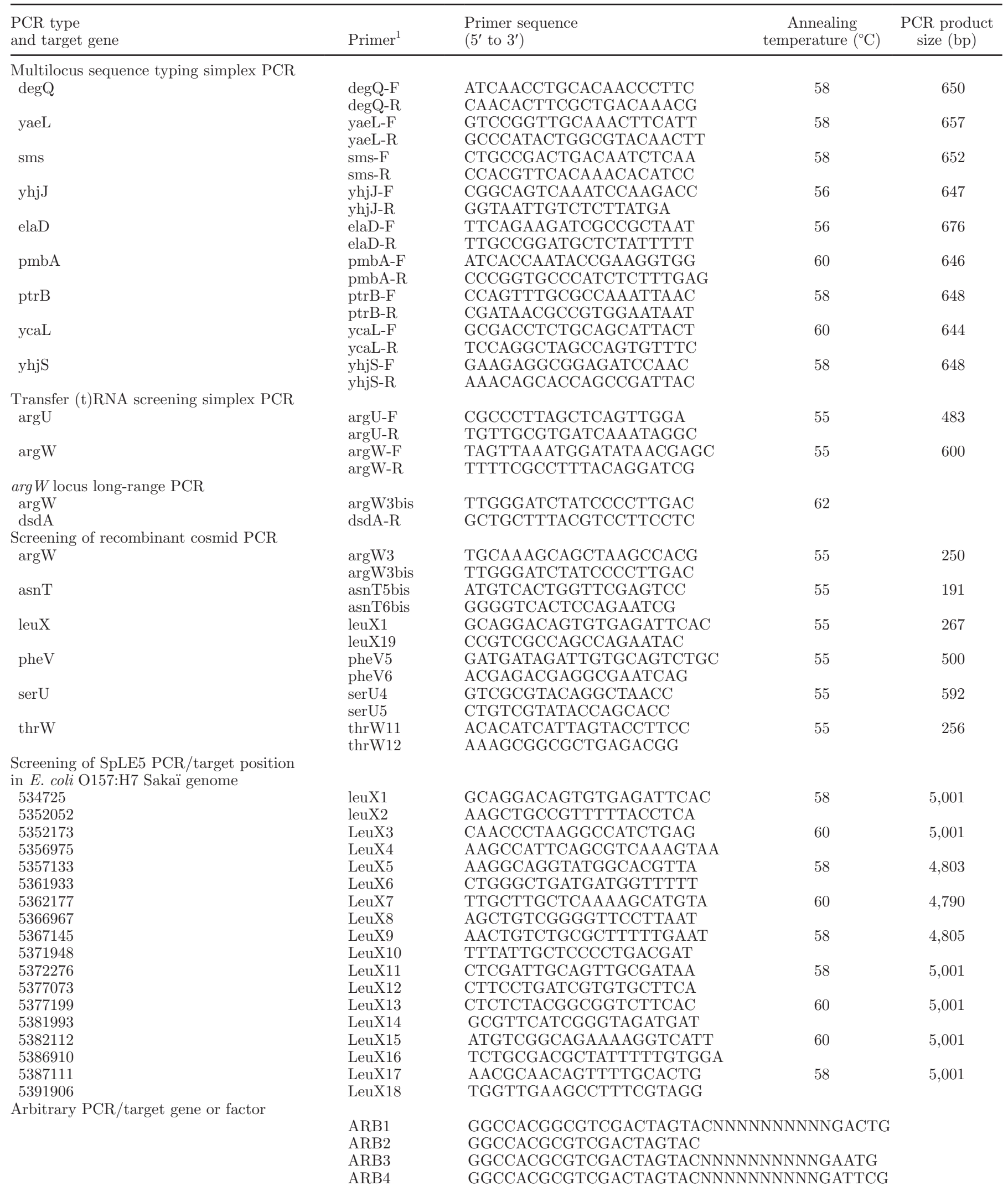


Table 1 (Continued). Primers for PCR designed during this study

\begin{tabular}{|c|c|c|c|c|}
\hline $\begin{array}{l}\text { PCR type } \\
\text { and target gene }\end{array}$ & Primer $^{1}$ & $\begin{array}{l}\text { Primer sequence } \\
\left(5^{\prime} \text { to } 3^{\prime}\right)\end{array}$ & $\begin{array}{c}\text { Annealing } \\
\text { temperature }\left({ }^{\circ} \mathrm{C}\right)\end{array}$ & $\begin{array}{l}\text { PCR product } \\
\text { size (bp) }\end{array}$ \\
\hline $\arg W$ & $\operatorname{argW1ter}$ & CTCCATTAGCGGGTATACTCATGCC & & \\
\hline \multirow[t]{2}{*}{$\operatorname{asn} T$} & asnT-F & TAAGTAATATGCGCCCCGTTC & & \\
\hline & asnT3bis & TAGTTCAGTCGGTAGAACGG & & \\
\hline \multirow[t]{2}{*}{$\operatorname{asp} V$} & aspV-F & GGCGGAAGCTGCCTCTGGCG & & \\
\hline & aspV3 & TTCCCAACGGAACACAACGC & & \\
\hline \multirow[t]{2}{*}{ pheV } & pheV3bis & GATGATAGATTGTGCAGTCTGC & & \\
\hline & pheV-F & ACGAGACGAGGCGAATCAG & & \\
\hline \multirow{2}{*}{$\operatorname{ser} U$} & serU3 & GAACAAAATTGCACGGACAG & & \\
\hline & serU-F & TCCTGGCATCATGGCAACC & & \\
\hline \multirow[t]{2}{*}{$\operatorname{thr} W$} & thrW1 & AAGGCCATTGACGCATCGC & & \\
\hline & thrW3 & TGAACATGTCCTTTCAGGGC & & \\
\hline
\end{tabular}

${ }^{1} \mathrm{~F}=$ forward, $\mathrm{R}=$ reverse.

nucleotide sequence of the region located downstream from the $\arg W$ locus, which was amplified by arbitrary PCR and sequenced, and with the reverse primer dsdA$\mathrm{R}$, designed from the complete genome sequence of $E$. coli K-12 MG1655.

\section{PCR Amplification}

A My Cycler thermocycler (BioRad, Bristol, UK) was used for the different amplification procedures, which are presented in Table 2. The PCR reactions were performed in a volume of $50 \mu \mathrm{L}$ with about 200 ng of genomic DNA. Either 1 or $1.25 \mathrm{U}$ of Taq DNA Polymerase (BioRad) was routinely used, except for the arbitrary PCR, in which $5 \mathrm{U}$ was used. One unit of Accu Taq DNA polymerase (Sigma, Dorset, UK) was used for the screening of the asn $U V W$, pheV, asp $V$, $g l y U$, and $\operatorname{ser} X$ tRNA loci and of the prophage-like element SpLE5 PCR, whereas 2.5 U was used for the amplification of the $\arg W$ tRNA locus. Two hundred micromoles of each dNTP (BioRad) was used for each PCR, except for the traT gene PCR, in which $100 \mu M$ of each dNTP was used, and for the $\arg W$ tRNA locus, in which $500 \mu M$ of each dNTP were used. One micro-

Table 2. Polymerase chain reaction amplification procedures used in this study

\begin{tabular}{|c|c|c|c|c|}
\hline Procedure & $\begin{array}{l}\text { Initial } \\
\text { denaturation step }\end{array}$ & $\begin{array}{l}\text { Amplification } \\
\text { cycles }^{1}\end{array}$ & $\begin{array}{l}\text { Number } \\
\text { of cycles }\end{array}$ & $\begin{array}{l}\text { Final elongation } \\
\text { step }\end{array}$ \\
\hline $\begin{array}{l}\text { Phylogenetic group, multilocus sequence typing, traT } \\
\text { gene, and screening of recombinant plasmid PCR }\end{array}$ & $94^{\circ} \mathrm{C}$ for $5 \mathrm{~min}$ & $\begin{array}{l}94^{\circ} \mathrm{C} \text { for } 30 \mathrm{~s} \\
\mathrm{~T}-30 \mathrm{~s} \\
72^{\circ} \mathrm{C} \text { for } 30 \mathrm{~s}\end{array}$ & 30 & $72^{\circ} \mathrm{C}$ for $7 \mathrm{~min}$ \\
\hline $\begin{array}{l}\text { Screening transfer (t)RNA of } \operatorname{asn} \mathrm{T}, \arg \mathrm{U}, \arg \mathrm{W}, \operatorname{leu\mathrm {X}} \text {, } \\
m e t \mathrm{~V}, \text { phe } \mathrm{U}, \text { phe } \mathrm{V}, \operatorname{sel\mathrm {C}}, \operatorname{ser} \mathrm{U}, \operatorname{ser} \mathrm{W}, t h r \mathrm{~W} \text { loci } \mathrm{PCR}\end{array}$ & $94^{\circ} \mathrm{C}$ for $5 \mathrm{~min}$ & $\begin{array}{l}95^{\circ} \mathrm{C} \text { for } 1 \mathrm{~min} \\
\mathrm{~T}-1 \mathrm{~min} \\
72^{\circ} \mathrm{C} \text { for } 1 \mathrm{~min}\end{array}$ & 30 & $72^{\circ} \mathrm{C}$ for $7 \mathrm{~min}$ \\
\hline Internal transcribed spacer $16 \mathrm{~S}-23 \mathrm{~S}$ PCR & $95^{\circ} \mathrm{C}$ for $3 \mathrm{~min}$ & $\begin{array}{l}95^{\circ} \mathrm{C} \text { for } 1 \mathrm{~min} \\
\mathrm{~T}-50 \mathrm{~s} \\
72^{\circ} \mathrm{C} \text { for } 2 \mathrm{~min}\end{array}$ & 35 & $72^{\circ} \mathrm{C}$ for $10 \mathrm{~min}$ \\
\hline $\arg \mathrm{W}$ tRNA locus long-range PCR & $94^{\circ} \mathrm{C}$ for $1 \mathrm{~min}$ & $\begin{array}{l}98^{\circ} \mathrm{C} \text { for } 10 \mathrm{~s} \\
\mathrm{~T}-30 \mathrm{~s} \\
72^{\circ} \mathrm{C} \text { for } 20 \mathrm{~min}\end{array}$ & 30 & $72^{\circ} \mathrm{C}$ for $10 \mathrm{~min}$ \\
\hline Second step of arbitrary PCR & $95^{\circ} \mathrm{C}$ for $5 \mathrm{~min}$ & $\begin{array}{l}95^{\circ} \mathrm{C} \text { for } 30 \mathrm{~s} \\
52^{\circ} \mathrm{C} \text { for } 30 \mathrm{~s} \\
72^{\circ} \mathrm{C} \text { for } 2 \mathrm{~min}\end{array}$ & 30 & None \\
\hline
\end{tabular}

\footnotetext{
${ }^{1} \mathrm{~T}=$ annealing temperature specified for each PCR type or target gene in Table 1.
} 
mole of each primer was used for each PCR, except for the $\arg W$ tRNA locus, traT gene, and arbitrary PCR, in which $0.4,0.3$, and $0.8 \mu M$ were used, respectively.

\section{DNA Sequence Analysis, Sequence Annotation, and Nucleotide Sequence Accession Numbers}

Sequencing was carried out by the Genome Express Society (Grenoble, France) according to the method of Sanger. Homology searches of homology were carried out using the BLAST programs of the National Center for Biotechnology Information (http://www.ncbi.nlm.nih. gov/BLAST/). Putative conserved domain sequences (CDS) were identified using the CDS Finder program of the National Center for Biotechnology Information (http://www.ncbi.nlm.nih.gov/gorf/gorf.html), and the Glimmer program of the Nano + Bio Center (http:// www.nbz.uni-kl.de/). Conserved domains of putative CDS were searched by using the Conserved Domain Database (CDD) program of the National Center for Biotechnology Information (http://www.ncbi.nlm.nih. gov/Structure/cdd/wrpsb.cgi). Ribosome binding sites (RBS) and rho-independent terminator were searched by using the RBS Finder and Trans Term programs of the Nano + Bio Center (http://www.nbz.uni-kl.de/).

Escherichia coli $\mathrm{P} 4$-specific sequences of the cyaA, grpE, $m t l D$, elaD, pmbA, and sms genes, and of the $\arg W, \operatorname{asn} T$, leuX, pheV (2 sequences), ser $U$, and thr $W$ tRNA loci determined in this study were submitted to the EMBL nucleotide sequence database, and are available under accession numbers EU876896, EU876897, EU876898, EU876899, EU876900, EU876901, and EU876907, EU876902, EU876904, EU876905EU876906, EU876908, and EU876903, respectively.

\section{RESULTS}

\section{Phylogenetic Analyses of E. coli P4}

We began this study by determining to which of the 4 main phylogenetic groups (A, B1, B2, and D) of the E. coli (Selander et al., 1987; Herzer et al., 1990) the strain $\mathrm{P} 4$ belonged. To this end, we used the PCR assay described by Clermont et al. (2000). The strain E. coli K-12 MG1655 was used as control. Only the yjaA gene was detected in E. coli $\mathrm{P} 4$ (and confirmed by sequencing), as in the control E. coli K-12 MG1655, suggesting that E. coli $\mathrm{P} 4$ belongs to the phylogenetic group A.

This result was confirmed by performing a MLST analysis, based on the sequence comparison of several genes belonging to the core genome of the $E$. coli species. An internal fragment of 29 genes, most of which had been already used in several MLST studies, was thus amplified from E. coli $\mathrm{P} 4$ and sequenced. Among the 29 core genes, only 6 did not share $100 \%$ identity with the corresponding genes of $E$. coli K-12 MG1655. The cyaA, grpE, mtlD, elaD, and $p m b A$ sequences shared $99.8,99.75,99.81,99.75$, and $98.72 \%$ identity with those of E. coli K-12 MG1655, respectively. In each case, they remained closer to the same genes in the E. coli K-12 MG1655 genome. Conversely, the sms sequence shared 98.25\% identity with that of E. coli O157:H7 Sakai. By comparing these results with those of the EcMLST database (Reid et al., 2002), we confirmed that E. coli P4 actually belongs to the phylogenetic group A and is phylogenetically closer to the E. coli K-12 MG1655 strain, a commensal and nonpathogenic strain of the phylogenetic group A.

\section{Detection of GEI in E. coli P4 Genome by tRNA Screening}

We then investigated whether E. coli $\mathrm{P} 4$ could contain potential virulence genes. We searched by PCR for several virulence factors known in other E. coli pathotypes to confer cellular adhesion, invasion, or proteolytic properties, but no amplicon was obtained (data not shown). Finally, only the traT gene, encoding a serum resistance factor, was detected by PCR in the genome of $E$. coli $\mathrm{P} 4$ and confirmed by sequencing.

Genes conferring specific properties to particular $E$. coli strains are frequently located on GEI, themselves often being located downstream of tRNA genes (Hou, 1999). To identify new genes in the E. coli $\mathrm{P} 4$ strain that could explain its specific properties, we thus looked for potential GEI downstream of tRNA genes using a PCR-based tRNA screening to detect sequence context alterations around the tRNA genes. Because the above phylogenetic analyses indicated that E. coli P4 was closely related to E. coli K-12 MG1655, this strain was used as a control. Size differences between the PCR products obtained from the 2 genomes or the absence of the expected amplicon from the genome of E. coli $\mathrm{P} 4$ indicated a genomic variation and possibly a chromosomal integration of foreign DNA at the $3^{\prime}$ end of the tRNA gene tested. We screened $17(\arg U, \arg W$, asn $T$, asn $U V W$, asp $V$, glyU, leuX, met $V$, phe $U$, phe $V$, $\operatorname{sel} C, \operatorname{ser} U, \operatorname{ser} W, \operatorname{ser} X$, and $\operatorname{thr} W$ ) out of 36 likely acceptor tRNA genes because they had been previously shown to be the loci that are the most frequently associated with GEI (Germon et al., 2007). In strain P4, sequence context variations were detected in 7 of them $(\arg W, \operatorname{asn} T, \operatorname{asp} V$, leuX, phe $V$, serU, and thr $W$ ). For $\arg W, \operatorname{asn} T, \operatorname{asp} V, \operatorname{leu} X, \operatorname{ser} U$, and thr $W$ loci, no amplicon was obtained, whereas one amplicon of unexpected size (2,208 bp vs. 623 bp for K-12) was obtained for the phe $V$ locus. Therefore, these results suggested the presence of genomic variations at the $3^{\prime}$ end of these 7 tRNA loci in the E. coli $\mathrm{P} 4$ genome. 


\section{Sequence Analysis of the Region Located Downstream from the argW, asnT, leuX, pheV, serU, and thrW tRNA Loci}

The regions located immediately downstream from 6 $(\arg W$, asn $T$, leuX, pheV, serU, and thr $W$ ) out of the 7 altered tRNA loci were amplified from the E. coli P4 genome by arbitrary PCR. Fragments of $747 \mathrm{bp}$ (ArgW-P4), 202 bp (AsnT-P4), 1,335 bp (LeuX-P4), 1,677 bp (PheV-P4), 755 bp (SerU-P4), and 696 bp (ThrW-P4) were obtained for the $\arg W, \operatorname{asn} T$, leuX, phe $V$, serU, and thr $W$ loci, respectively, and were sequenced (Table 3). Their $\mathrm{G}+\mathrm{C}$ content ranged from 40.1 to $47.56 \%$. In each case, the sequences shared similarities with a sequence located at the same locus in another E. coli strain. An open reading frame (ORF) encoding a putative integrase was observed in the leuX$\mathrm{P} 4$ and pheV-P4 sequences (Table 3). It appeared to be functional in the case of pheV-P4 and truncated in the case of leuX-P4. Because the integrase detected in this latter case shared similarities with an integrase of the prophage-like element SpLE5 of E. coli O157:H7 Sakai, 9 pairs of primers specific to this prophage were designed and used in PCR reactions to determine whether such an element was present in E. coli P4. Genomic DNA of E. coli O157:H7 EDL933 and E. coli K-12 MG1655 were used as positive and negative controls, respectively. No amplicon with the expected size was obtained for strain P4: PCR products were either smaller than expected or completely absent. The PCR products obtained with the primers leuX1/X2, leuX3/X4, leuX5/X6, leuX13/X14, leuX15/X16, and leuX17/X18 were sequenced. They displayed 70 to $98 \%$ identity with the corresponding regions of the SpLE5 element. Thus, it appeared that an altered structure of the prophage-like element SpLE5 is present in the E. coli $\mathrm{P} 4$ genome. Finally, the 2,208-bp PCR product obtained during the phe $V$-tRNA screening (see above) was also sequenced. This sequence had a $\mathrm{G}+\mathrm{C}$ content of $49.60 \%$ and displayed identities $(>80 \%)$ with different genomic fragments of the LEE-PAI of the bovine shiga toxin-producing E. coli RW1473 strain (GenBank accession number: AJ303141). Its last 333 nucleotides also displayed $100 \%$ identity with the first 333 nucleotides of the $y g h D$ gene of E. coli K-12 MG1655 genome, which is the first conserved gene found in the $E$. coli genomes downstream from the phe $V$ tRNA locus. From the positions 1,705 to 1,727 , a 23 -bp sequence was identified that was $100 \%$ identical to the last 23 nucleotides of phe $V$ gene. This 23-bp sequence has been previously identified as the target of recombination events at the phe $U$ and phe $V$ loci in enteropathogenic and enterohemorrhagic E. coli (Rumer et al., 2003). Consequently, this 2,208-bp region seems to represent the $3^{\prime}$ end of a
GEI located downstream from the phe $V$ locus in the $E$. coli $\mathrm{P} 4$ genome. Computer analysis revealed the presence of 3 ORF (ORF1-pheV, 2-pheV, and 3-pheV, Table 4). They encoded hypothetical proteins similar to proteins with unknown function of the commensal strain E. coli Nissle 1917, the enteropathogen strain E. coli $\mathrm{B} 7 \mathrm{~A}$, and the bovine enterohemorrhagic strain E. coli RW1374, respectively. Thus, the region located downstream of the phe $V$-tRNA locus in the E. coli $\mathrm{P} 4$ genome seemed to have a composite structure.

To conclude, analyses of the regions located immediately downstream of the $\arg W$, asn $T$, leuX, phe $V$, $\operatorname{ser} U$, and $\operatorname{thr} W$ loci of $E$. coli $\mathrm{P} 4$ revealed, in each case, presence of sequences different from those present at the corresponding loci in the E. coli K-12 MG1655 genome. In the case of the phe $V$ locus, the analysis of this sequence strongly suggested the presence of a GEI in $E$. coli $\mathrm{P} 4$, whereas no foreign DNA was inserted at this locus in E. coli K-12 MG1655 genome. For the leuX locus, an altered structure of E. coli O157:H7 Sakai SpLE5 seemed to be present in E. coli $\mathrm{P} 4$ genome, whereas another prophage-like element (KpLE2) with different genomic content is identified at this locus in E. coli K-12 MG1655 genome.

\section{Partial Sequence Analysis of the GEI Located Downstream from the serU tRNA Locus in E. coli P4 Genome}

To characterize the regions located downstream from the identified altered tRNA loci in E. coli $\mathrm{P} 4$, a genomic library was constructed using pWEB:Tnc as vector. Recombinant cosmids containing the regions of interest were selected by PCR and reconfirmed by hybridization using appropriate PCR products specific to the targeted regions as probes. One recombinant cosmid containing the $\operatorname{ser} U$ locus was identified and partially sequenced. A nucleotide sequence of a 13,202-bp region downstream from the $\operatorname{ser} U$ locus was determined. This sequence presented a $\mathrm{G}+\mathrm{C}$ content of $42.5 \%$. Seven ORF (Figure 1) were detected, 4 of which (ORF3-serU, 5-ser $U, 6$-ser $U$, and 7-ser $U$ ) encode putative proteins with DNA mobility function, such as transposases and integrases. The ORF1-ser $U$ encodes a protein that is related to glycosylation function of the $\mathrm{O}$-antigen part of LPS, the ORF4-serU encodes a protein of unknown function, and the protein encoded by the ORF2-ser $U$ has no significant similarity with any protein of the GenBank database. Proteins similar to those encoded by these 7 ORF seem to have different origin such as bacteriophage DNA (ORF1-serU, and 7-serU), bacterial chromosome DNA (ORF3-serU, and 6-serU), and bacterial plasmid (ORF4-serU, and 5-ser $U$, which both are components of the Tn1000 of the F plasmid). Thus, 


\begin{tabular}{|c|c|c|c|c|c|c|c|c|c|}
\hline \multirow[b]{2}{*}{$\begin{array}{l}\text { Transfer } \\
\text { (t)RNA locus }\end{array}$} & \multirow[b]{2}{*}{ Sequence } & \multirow[b]{2}{*}{$\begin{array}{c}\mathrm{G}+\mathrm{C} \\
\text { content }(\%)\end{array}$} & \multirow[b]{2}{*}{$\begin{array}{l}\text { Ribosome } \\
\text { binding site }\end{array}$} & \multirow[b]{2}{*}{$\begin{array}{l}\text { Open reading } \\
\text { frame } \\
\text { position }\end{array}$} & \multirow[b]{2}{*}{$\begin{array}{l}\text { Predicted } \\
\text { size (AA) }\end{array}$} & \multicolumn{4}{|c|}{ Characteristics of homologous sequence } \\
\hline & & & & & & $\begin{array}{l}\text { Identity/ } \\
\text { similarity }(\%)\end{array}$ & $\begin{array}{l}\text { Homologous } \\
\text { fragment or } \\
\text { putative function }\end{array}$ & $\begin{array}{l}\text { Species } \\
\text { and strain }\end{array}$ & $\begin{array}{l}\text { Accession } \\
\text { number }\end{array}$ \\
\hline $\operatorname{argW}$ & $\operatorname{argW-P4}$ & 43.11 & - & - & - & 94 & 627-bp fragment & $\begin{array}{l}\text { Escherichia coli } \\
\text { APEC BEN1588 }\end{array}$ & DQ023206 \\
\hline $\operatorname{asnT}$ & asnT-P4 & 40.1 & - & - & - & 96 & 195-bp fragment & E. coli C ATCC 8739 & CP000946 \\
\hline leuX & LeuX-P4 & 46.59 & $\begin{array}{l}\text { AGGCGG } \\
\text { and AGGGT }\end{array}$ & $91-1065$ & 324 & $69 / 76$ & Integrase & E. coli O157:H7 Sakai & BAB38665 \\
\hline pheV & pheV-P4 & 46.57 & - & $198-1460$ & 420 & $90 / 95$ & P4-type integrase & Shigella flexneri 2 a strain 301 & AAN44445 \\
\hline serU & SerU-P4 & 44.11 & - & - & - & 79 & 716-bp fragment & E. coli HS & CP000802 \\
\hline thrW & ThrW-P4 & 47.56 & - & - & - & 98 & 696-bp fragment & $\begin{array}{l}\text { S. flexneri } 2 \text { a strain } 301 \text { and } \\
\text { E. coli } \mathrm{O} 157: \mathrm{H}^{2} \text { Sakai }^{1}\end{array}$ & - \\
\hline
\end{tabular}

${ }^{1}$ In S. flexneri 2a 301 and E. coli O157:H7 Sakai, the corresponding sequences contain the last moiety and the last two-thirds of an open reading frame encoding a putative integrase.

Table 4. Open reading frames (ORF) detected within the 1,875 bp located downstream from the pheV-tRNA locus

\begin{tabular}{|c|c|c|c|c|c|c|c|c|c|c|}
\hline \multirow[b]{2}{*}{$\mathrm{ORF}$} & \multirow[b]{2}{*}{ Position } & \multirow[b]{2}{*}{$\begin{array}{l}\text { Ribosome } \\
\text { binding site }\end{array}$} & \multirow[b]{2}{*}{$\begin{array}{c}\mathrm{G}+\mathrm{C} \\
\text { content }(\%)\end{array}$} & \multirow[b]{2}{*}{$\begin{array}{l}\text { Predicted } \\
\text { size (AA) }\end{array}$} & \multirow[b]{2}{*}{$\begin{array}{l}\text { Accession } \\
\text { number }\end{array}$} & \multirow[b]{2}{*}{$\begin{array}{c}\text { Conserved } \\
\text { domain }\end{array}$} & \multicolumn{4}{|c|}{ Characteristics of homologous protein } \\
\hline & & & & & & & $\begin{array}{l}\text { Function and } \\
\text { accession number }\end{array}$ & $\begin{array}{l}\text { Species } \\
\text { (strain) }\end{array}$ & $\begin{array}{l}\text { Length } \\
\text { (AA) }\end{array}$ & $\begin{array}{c}\text { Identity/ } \\
\text { similarity }(\%)\end{array}$ \\
\hline ORF1-pheV & $370-816$ & - & 53.2 & 148 & ACG50150 & - & $\begin{array}{l}\text { Hypothetical protein } \\
\text { (CAE55810) }\end{array}$ & $\begin{array}{l}\text { Escherichia . coli } \\
\text { (Nissle 1917) }\end{array}$ & 143 & $91 / 94$ \\
\hline ORF2-pheV & $683-925$ & - & 49.6 & 80 & ACG50151 & - & $\begin{array}{l}\text { Hypothetical protein } \\
\text { (ZP_0076238.1) }\end{array}$ & E. $\operatorname{coli}(\mathrm{B} 7 \mathrm{~A})$ & 80 & $98 / 100$ \\
\hline ORF3-pheV & $1,022-1,594$ & $\begin{array}{l}\text { AGGAA, } \\
1,009-1,013\end{array}$ & 45.8 & 190 & ACG50152 & - & $\begin{array}{l}\text { Hypothetical protein } \\
\text { (CAI43851) }\end{array}$ & E. coli (RW1374) & 190 & $98 / 98$ \\
\hline
\end{tabular}


A.

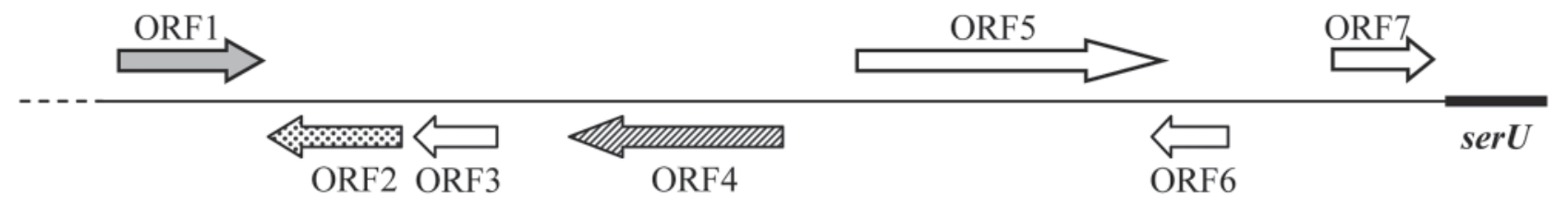

$\Rightarrow$ ORF related to mobile genetic function

$\Rightarrow$ ORF related to glycosylation function

ORF with no significant similarity in the database

ORF related to unknown function

B.

\begin{tabular}{|c|c|c|c|c|c|c|c|c|c|c|}
\hline \multirow[b]{2}{*}{ ORF } & \multirow[b]{2}{*}{ Position } & \multirow[b]{2}{*}{ RBS } & \multirow[b]{2}{*}{$\begin{array}{l}\mathrm{G}+\mathrm{C} \\
\text { content } \\
(\%)\end{array}$} & \multirow[b]{2}{*}{$\begin{array}{l}\text { Predicted } \\
\text { size (aa) }\end{array}$} & \multirow[b]{2}{*}{$\begin{array}{c}\text { Accession } \\
\text { number }\end{array}$} & \multirow[b]{2}{*}{$\mathrm{CD}$} & \multicolumn{4}{|c|}{ Characteristic of homologous protein } \\
\hline & & & & & & & $\begin{array}{l}\text { Function } \\
\text { (Accession } \\
\text { number) } \\
\end{array}$ & $\begin{array}{l}\text { Species } \\
\text { (strain) }\end{array}$ & $\begin{array}{l}\text { Lenght } \\
\text { (aa) }\end{array}$ & $\begin{array}{l}\text { \%Identity/ } \\
\text { \%similarity }\end{array}$ \\
\hline $\begin{array}{l}\text { ORF1- } \\
\operatorname{ser} U\end{array}$ & $168-1580$ & $\begin{array}{l}\text { AGGGG } \\
(96-100)\end{array}$ & 32.7 & 470 & ACG50163 & l & $\begin{array}{c}\text { O-antigen } \\
\text { conversion } \\
\text { protein } \\
(\mathrm{NP} 720275)\end{array}$ & $\begin{array}{l}\text { Entero- } \\
\text { bacteriophage } \\
\text { (ST64T) }\end{array}$ & 485 & $24 / 45$ \\
\hline $\begin{array}{l}\text { ORF2- } \\
\text { serU }\end{array}$ & $2941-1625$ & $\begin{array}{c}\text { AGGGG } \\
(2996-2992)\end{array}$ & 39.6 & 438 & ACG50164 & l & / & / & I & / \\
\hline $\begin{array}{c}\text { ORF3- } \\
\text { serU }\end{array}$ & $3886-3074$ & $\begin{array}{c}\text { AGCGG } \\
(3973-3969)\end{array}$ & 50.3 & 270 & ACG50165 & $\begin{array}{l}\text { Integrase/ } \\
\text { Transposase } \\
\text { (entire) }\end{array}$ & $\begin{array}{l}\text { IShe3 transposase } \\
\text { (YP_001456923) }\end{array}$ & E. coli $(\mathrm{HS})$ & 270 & 99/99 \\
\hline $\begin{array}{l}\text { ORF4- } \\
\text { serU }\end{array}$ & $6702-4600$ & $\begin{array}{l}\text { AGGGG } \\
(6794-6790)\end{array}$ & 34.3 & 700 & ACG50166 & l & $\begin{array}{c}\text { TnpX } \\
\text { hypothetical } \\
\text { protein } \\
\text { (NP_061387) }\end{array}$ & Plasmid F & 698 & $100 / 100$ \\
\hline $\begin{array}{l}\text { ORF5- } \\
\text { serU }\end{array}$ & $7427-10435$ & $\begin{array}{c}\text { GGGAG } \\
(7416-7420)\end{array}$ & 48.5 & 1002 & ACG50167 & $\begin{array}{c}\text { Transposase } \\
\text { (entire) }\end{array}$ & $\begin{array}{l}\text { TnpA transposase } \\
\text { (NP_061389) }\end{array}$ & Plasmid F & 1002 & $100 / 100$ \\
\hline $\begin{array}{l}\text { ORF6- } \\
\text { serU }\end{array}$ & $11117-10359$ & l & 46.2 & 252 & ACG50168 & $\begin{array}{c}\text { Transposase } \\
\text { (partial) }\end{array}$ & $\begin{array}{l}\text { IS30 transposase } \\
\text { (YP_001451392) }\end{array}$ & $\begin{array}{c}\text { E. coli } \\
\text { (E24377A) }\end{array}$ & 383 & $100 / 100$ \\
\hline $\begin{array}{c}\text { ORF7- } \\
\operatorname{ser} U\end{array}$ & $12098-13087$ & l & 44.7 & 329 & ACG50169 & $\begin{array}{l}\text { Integrase } \\
\text { (entire) }\end{array}$ & $\begin{array}{c}\text { Integrase } \\
\text { (NP_700401) }\end{array}$ & $\begin{array}{c}S \\
\text { typhimurium } \\
\text { phage } \\
\text { (ST64B) }\end{array}$ & 329 & $84 / 94$ \\
\hline
\end{tabular}

Figure 1. (A) Partial genetic map of the serU genomic region of Escherichia coli $\mathrm{P} 4$; (B) characteristics of the open reading frames (ORF) detected within the $E$. coli $\mathrm{P} 4 \operatorname{ser} U$ genomic island partially characterized. RBS = ribosome binding site, sequence and position; CD = conserved domain.

this partial sequence suggests that the $\operatorname{ser} U$ region of $E$. coli $\mathrm{P} 4$ genome presented a mosaic structure.

\section{Sequence Analysis of the GEI Located Downstream from the argW tRNA Locus in E. coli P4 Genome}

General Features. As the ArgW-P4 sequence presented no homology with any of the sequenced $E$. coli genomes, we decided to sequence the entire variable genomic region located downstream from the $\arg W$ locus. A forward primer specific to the ArgW-P4 sequence and a reverse primer specific to the sequence of the $d s d A$ gene (first conserved gene found in the $E$. coli genome downstream from the $\arg W$ tRNA locus) were designed and used to carry out long-range PCR. An amplicon of about $12 \mathrm{~kb}$ was obtained and sequenced. After removing the nucleotide fragments corresponding to the $\arg W$ and $d s d A$ genes, a genomic region of 11,253 bp was defined. It displayed an averaged $\mathrm{G}+\mathrm{C}$ content of $40.92 \%$ and varied across this region from 31.2 to $48.73 \%$ (Figure 2). From the positions 8,628 to 8,650, a 23-bp sequence was identified that was identical to the 
A.

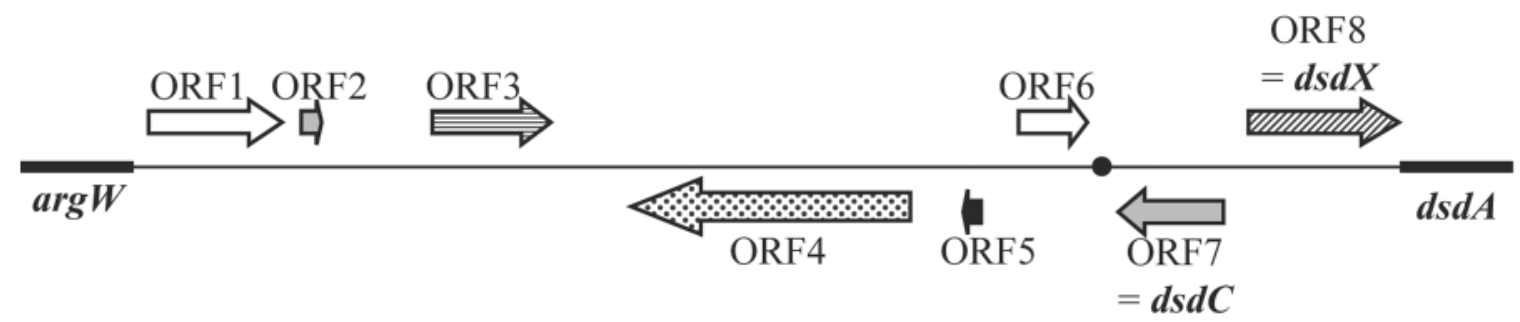

$\square$ ORF related to mobile genetic function

$\Rightarrow$ ORF related to transcription DNA function

$\vec{E}$ ORF related to replication DNA function

$\Leftrightarrow$ ORF related to deacetylation function

ORF related to transporter function

$\Rightarrow$ ORF related to unknown function

- Direct repeat of the last 23 nucleotides of the $\arg W$ gene

B.

\begin{tabular}{|c|c|c|c|c|c|c|c|c|c|c|}
\hline \multirow[b]{2}{*}{ ORF } & \multirow[b]{2}{*}{ Position } & \multirow[b]{2}{*}{ RBS } & \multirow[b]{2}{*}{$\begin{array}{c}\mathrm{G}+\mathrm{C} \\
\text { content } \\
(\%)\end{array}$} & \multirow[b]{2}{*}{$\begin{array}{l}\text { Predicted } \\
\text { size (aa) }\end{array}$} & \multirow[b]{2}{*}{$\begin{array}{c}\text { Accession } \\
\text { number }\end{array}$} & \multirow[b]{2}{*}{$\mathrm{CD}$} & \multicolumn{4}{|c|}{ Characteristic of homologous protein } \\
\hline & & & & & & & $\begin{array}{l}\text { Function } \\
\text { (Accession } \\
\text { number) }\end{array}$ & Species (strain) & $\begin{array}{l}\text { Lenght } \\
\text { (aa) }\end{array}$ & $\begin{array}{l}\text { \%Identity/ } \\
\text { \%similarity }\end{array}$ \\
\hline $\begin{array}{l}\text { ORF1 } \\
-\arg W\end{array}$ & $165-1355$ & $\begin{array}{l}\text { AGGGG } \\
(127-131)\end{array}$ & 43.07 & 396 & ACG50154 & $\begin{array}{l}\text { P4 integrase } \\
\text { (partial) }\end{array}$ & $\begin{array}{c}\text { Integrase } \\
\text { (YP_153333) }\end{array}$ & $\begin{array}{l}\text { Salmonella enterica } \\
\quad \text { (ATCC9150) }\end{array}$ & 419 & $68 / 82$ \\
\hline $\begin{array}{l}\text { ORF2 } \\
-\arg W\end{array}$ & $1512-1703$ & $\begin{array}{c}\text { GAGG } \\
(1503-1506)\end{array}$ & 46.88 & 63 & ACG50155 & $\begin{array}{l}\text { Transcriptional } \\
\text { regulator } \\
\text { (entire) }\end{array}$ & $\begin{array}{c}\text { Predicted } \\
\text { transcriptional } \\
\text { regulator } \\
(\mathrm{ZP} \text { _00834742) }\end{array}$ & $\begin{array}{l}\text { Yersinia intermedia } \\
\quad \text { (ATCC29909) }\end{array}$ & 65 & 73/91 \\
\hline $\begin{array}{l}\text { ORF3 } \\
\text {-argW }\end{array}$ & $2671-3723$ & & 43.59 & 350 & ACG50156 & / & $\begin{array}{c}\text { Putative } \\
\text { replication } \\
\text { protein } \\
\text { (NP_311263) }\end{array}$ & $\begin{array}{l}\text { E. coli }(\mathrm{O} 157: \mathrm{H} 7 \\
\text { Sakaï) }\end{array}$ & 231 & 97/99 \\
\hline $\begin{array}{l}\text { ORF4 } \\
\text { - } \arg W\end{array}$ & $6910-4430$ & $\begin{array}{l}\text { AAGAG } \\
(6921-6917)\end{array}$ & 31.20 & 826 & ACG50157 & Sir2 (entire) & $\begin{array}{l}\text { Hypothetical } \\
\text { protein } \\
\text { (YP_487138) }\end{array}$ & $\begin{array}{l}\text { Rhodopseudomonas } \\
\text { palustris (HaA2) }\end{array}$ & 792 & $23 / 41$ \\
\hline $\begin{array}{l}\text { ORF5 } \\
-\arg W\end{array}$ & $7564-7388$ & & 43.50 & 58 & ACG50158 & / & $\begin{array}{l}\text { Hypothetical } \\
\text { protein } \\
\text { (NP_311266) }\end{array}$ & $\begin{array}{l}\text { E. coli }(\mathrm{O} 157: \mathrm{H} 7 \\
\text { Sakaï) }\end{array}$ & 58 & $77 / 84$ \\
\hline $\begin{array}{l}\text { ORF6 } \\
\text {-argW }\end{array}$ & $7867-8493$ & & 47.69 & 208 & ACG50159 & $\begin{array}{c}\text { Recombinase/ } \\
\text { Resolvase } \\
\text { (entire) }\end{array}$ & $\begin{array}{c}\text { Putative } \\
\text { resolvase } \\
\text { (NP_311267) }\end{array}$ & $\begin{array}{l}\text { E. coli }(\mathrm{O} 157: \mathrm{H} 7 \\
\quad \text { Sakaï) }\end{array}$ & 208 & 98/99 \\
\hline $\begin{array}{l}\text { ORF7 } \\
\text {-argW }\end{array}$ & $9681-8746$ & $\begin{array}{c}\text { ATGAG } \\
(9692-9688)\end{array}$ & 48.08 & 311 & ACG50160 & $\begin{array}{l}\text { Transcriptional } \\
\text { regulator } \\
\text { (entire) }\end{array}$ & $\begin{array}{c}\text { DsdC } \\
\text { transcriptional } \\
\text { regulator } \\
\text { (AAC75424) }\end{array}$ & $\begin{array}{l}\text { E. coli (K12 } \\
\text { MG1655) }\end{array}$ & 311 & $100 / 100$ \\
\hline $\begin{array}{l}\text { ORF8 } \\
\text {-argW }\end{array}$ & $9899-11236$ & $\begin{array}{c}\text { AGGGG } \\
(9884-9888)\end{array}$ & 48.73 & 445 & ACG50161 & $\begin{array}{l}\text { Transporter } \\
\text { (entire) }\end{array}$ & $\begin{array}{c}\text { DsdX } \\
\text { predicted } \\
\text { transporter } \\
(\mathrm{AAC75425)}\end{array}$ & $\begin{array}{l}\text { E. coli (K12 } \\
\text { MG1655) }\end{array}$ & 445 & $100 / 100$ \\
\hline
\end{tabular}

Figure 2. (A) Genetic map of the $\arg W$ genomic region of Escherichia coli $\mathrm{P} 4$; (B) characteristics of the open reading frames (ORF) detected within the $E$. coli $\mathrm{P} 4 \arg W$ genomic island. $\mathrm{RBS}=$ ribosome binding site, sequence and position; $\mathrm{CD}=$ conserved domain. 
last 23 nucleotides of $\arg W$ gene. Thus, this genomic region exhibited several features typical of GEI: a chromosomal integration site located downstream from a tRNA locus, direct repeat of the $3^{\prime}$ end of this tRNA locus, large size, and atypical $\mathrm{G}+\mathrm{C}$ content.

ORF Content. Eight ORF were detected in this 11,253 nucleotides sequence (Figure 2). The ORF1$\arg W$ and ORF6- $\arg W$ encoded proteins with DNA mobility function; the ORF2- $\arg W$, ORF3- $\arg W$, and ORF7- $\arg W$ encoded proteins with replication or transcription functions; the ORF8- $\arg W$ encoded a protein with transport function; the ORF5- $\arg W$ encoded a protein of unknown function; and the ORF4- $\arg W$ encoded a protein with deacetylation function. The intergenic regions presented no similarity to any nucleotide sequence in the databases.

The deduced AA sequence of the putative protein encoded by the ORF1- $\arg W$ presented $68 \%$ identity and $82 \%$ similarity with the AA sequence of an integrase of the Salmonella enterica ATCC 9150 strain. The ORF1$\arg W$ conserved only the N-terminal domain of integrase; that is, the DNA binding domain, and lost the catalytic C-terminal domain. The C-terminal domain of the ORF1- $\arg W$ presented no significant degree of similarity with any protein sequence in the GenBank database. Consequently, the protein encoded by the ORF1-arg $W$ could be considered a chimeric protein, resulting from the association of a $\mathrm{N}$-terminal domain of a tyrosine recombinase with a fragment of unknown origin. The last 2 ORF detected (ORF7- $\arg W$ and ORF8-arg $W$ ) showed $100 \%$ identity with the 2 ORF located upstream from the $d s d A$ gene in the $E$. coli K-12 MG1655 genome; that is, $d s d C$ and $d s d X$ genes, respectively.

Sequence Analysis of ORF4-argW. The ORF4$\arg W$ was the largest ORF detected in the $\arg W$ GEI of $E$. coli $\mathrm{P} 4$. It consisted of 2,481 nucleotides and presented a $\mathrm{G}+\mathrm{C}$ content of $31.20 \%$, which was significantly lower than the average in E. coli. A predicted Shine-Dalgarno site (AAGAG) was identified $11 \mathrm{bp}$ upstream from the proposed start codon. A possible rho-independent transcriptional termination signal was also identified $14 \mathrm{bp}$ downstream from the proposed termination codon. This ORF4- $\arg W$ encoded a putative protein of $826 \mathrm{AA}$, with a deduced molecular mass of $95.18 \mathrm{kDa}$. From the position 27 to 223 of the AA sequence of this putative protein, a conserved domain of Silent Information Regulator 2 (Sir2) was detected. The Sir2 domain is characteristic of enzymes that catalyze $\mathrm{NAD}^{+}$-dependent protein/histone deacetylation. Such proteins have been identified in organisms ranging from bacteria to humans. They contain a series of consensus motifs grouped in a region of about 200 AA. The position of this region is highly variable in the total sequence of the Sir2 proteins, and AA sequences around this region can also be highly variable. Prokaryotic Sir2 proteins lack certain consensus motifs, as was the case for the protein encoded by the ORF4- $\arg W$ of E. coli $\mathrm{P} 4$, in which the consensus motifs GAGISXXXGIPXXR, TQNID, GTS, and (I/V)N were effectively identified with an altered composition (GAGFSRKTKNITNGEPPLA, TTNYD, GYS, and IV, respectively; Figure 3), and the consensus motifs PXXXH, HG, 2 sets of CXXC, and FGE were not identified. BlastP analyses showed that the N-terminal region of the putative protein encoded by ORF4- $\arg W$ was similar to that of Sir2 proteins. Its C-terminal region presented no significant degree of similarity with any protein sequence in the GenBank database.

\section{DISCUSSION}

Mastitis is a worldwide problem in dairy cattle and leads to multibillion-dollar economic losses because of treatment, culling, death of infected cows, and important losses of milk production (Sordillo and Streicher, 2002). Among bacteria responsible for this disease, $E$. coli is an important cause of clinical mastitis and yet the mastitis pathogens of this species remain poorly characterized compared with other pathogenic strains of $E$. coli. To our knowledge, no particular subset of genes shared by all strains of $E$. coli isolated from mastitis cases, which could permit better understanding their pathogenic properties, has been identified in epidemiological studies (Shpigel et al., 2008). It has been proposed that their virulence rather relies on microbeassociated molecular patterns such as LPS, which are present in all of these strains and that are detected by the host innate immune system (Shpigel et al., 2008).

We focused our attention on the E. coli strain P4 for several reasons. First, this strain has been isolated from a case of severe mastitis and is widely used to induce experimental mastitis. Second, E. coli $\mathrm{P} 4$ is able to grow in a high antibacterial environment such as milk obtained from mastitis induced with LPS (Dufour et al., 2009). Third, it has been reported that this strain displays adhesion or invasion properties on mammary gland epithelial cells in a murine model of acute mastitis (Gonen et al., 2007) and that it is able to induce apoptosis and proliferation of bovine mammary cells (Long et al., 2001). These data suggest that E. coli $\mathrm{P} 4$ may possess some specific properties or genes that, in addition to LPS, allow it to induce mastitis.

Identification of these potential virulence genes requires a detailed analysis of the genome of E. coli $\mathrm{P} 4$ but also of its transcriptome and of its proteome, especially during infection. This work was undertaken to initiate the genetic characterization of $E$. coli $\mathrm{P} 4$. As a first 


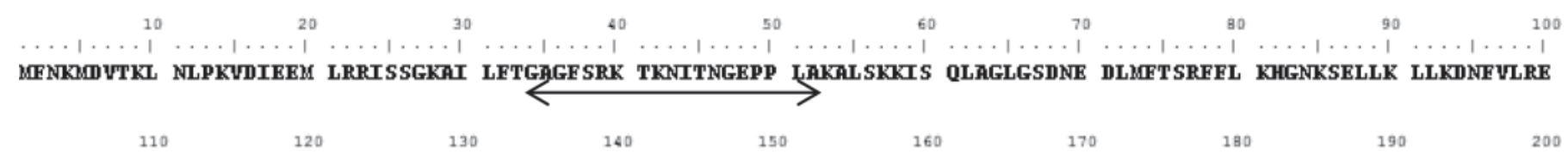

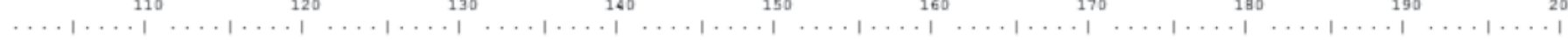
VSEYHEKICS LPURRFYTTN YDNSIELACL KTGRRIESLD IDDLPKDHIS QGDLCVHLNG AIDKAIISDL DSKIKLTNSS YLSPOSFISS QWNYVFKRDL

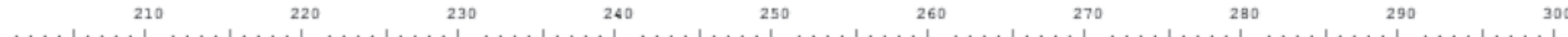
ETASAVIFVG YSIYDLDVQR LLYQTDSLVE KTYEYYHENA SFQETFFLTD FGHVLPIGVE GF SNLINDIQ FQSNENREEI CLDCFELKEI SYNHETITDT

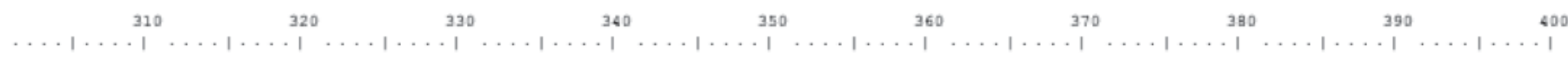
EIKDFLLFGK FDDNQINTSV SNDFLDNFLI NRDLLKETIR LIQSKNNILI HSELGNGKTV FLKUTTYLLA REGYNVYTES EKSEYDDELS EIDWIVKNKK

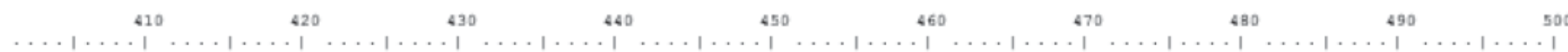
NVYTVIEGYN KAERLLNHIN INYPDEISII ITDRSAIALR TAYEINSLDI EFSEVSLDQL TESEISDFVD LIENQGLWSE LTSLSKINKI KKVKEDYNGO

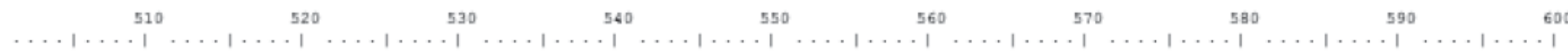

ISGILLGLLK SPSIOERTKY LTDELFKSOE YKDTUFAIAL CDIIDVRKTS SIISEMAGND STYKASLRSS DQFKSLYRFT ESGTAIETKS SLMSLAINN

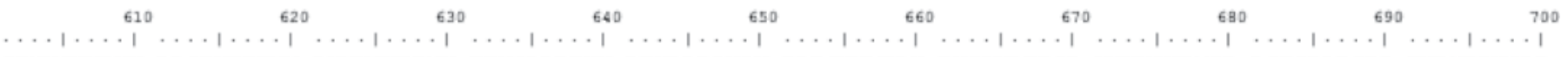

SFNUSYURYK LLSIVETFNN LKNUSYDANK IFKSLLRFHV LEULLPOKOK ALDSYYALLK RUCPWLTDSP HYWUOYAMCR LSIGDLDSAO TYLNDAYSLA

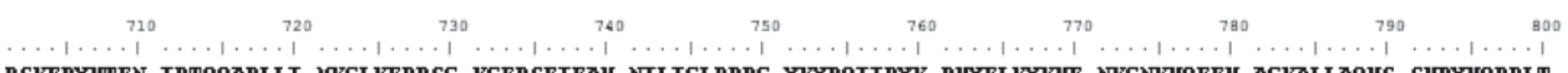

RSKEDYHTEN IDTQQARLLI MKCLKEPDSG KCFDSFIEAH NILIGLPDDG YKYROIIPYK DVYELKYKHF NKGNKVOFEH ACKALLAQVS SVDYHQDDLT

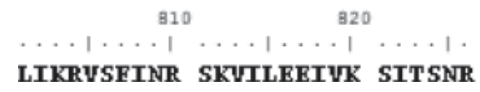

Figure 3. Predicted AA sequence of the protein encoded by the ORF4-argW of Escherichia coli P4. The double arrows indicate some of the conserved consensus motifs specific to the Sir2 proteins.

step, we identified to which of the 4 main phylogenetic groups of the $E$. coli species (namely, groups A, B1, B2, and D; Selander et al., 1987; Herzer et al., 1990) strain P4 belongs. Our data unambiguously demonstrate that E. coli $\mathrm{P} 4$ belongs to the phylogenetic group A. This group, like phylogenetic group B1, contains mainly commensal isolates, whereas groups B2 and D encompass intestinal and other extraintestinal pathogenic isolates (Picard et al., 1999). When analyzed in more detail, our result showed that the core genome of $E$. coli P4 is close to that of E.coli K-12 MG1655, a commensal strain. Indeed, all but 6 partial sequences of housekeeping genes of E. coli $\mathrm{P} 4$ shared $100 \%$ identity with those of $E$. coli K-12 MG1655. For 5 out of the 6 , we observed that their sequences remained closest to those of $E$. coli K-12 MG1655. Because the main habitat of this species is the intestine of humans or warm-blooded animals, the environment of cows is likely to contain numerous fecal E. coli strains. In addition, fecal and mammary pathogen strains belong to similar serotypes (Burvenich et al., 2003). It is therefore not surprising that E. coli $\mathrm{P} 4$ belongs to a phylogenetic group that includes numerous commensal strains and that its core genome is close to that of a commensal strain such as E. coli K-12 MG1655. Thus, these data support the hypothesis that E. coli $\mathrm{P} 4$, like other strains of $E$. coli isolated from mastitis cases, is an environmental pathogen that provokes transient infection of the mammary gland.

We refined this initial characterization, based on the core genome of $E$. coli $\mathrm{P} 4$, by characterizing genes belonging to its accessory gene repertoire, the set of genes likely to be responsible for particular properties of $E$. coli $\mathrm{P} 4$. In particular, it has been reported that, under specific conditions (toll-like receptor 4 knockout mice), E. coli $\mathrm{P} 4$ is capable of adhering to and invading epithelial cells of mammary gland in a murine model of acute mastitis, although the anatomy of the murine mammary gland is completely different from that of the bovine (Gonen et al., 2007), and of inducing apoptosis and proliferation of bovine mammary cells (Long et al., 2001). Using PCR, we tried to identify in E. coli P4 virulence factors that are present in other intestinal or extraintestinal pathogenic strains of E. coli. This approach allowed us to detect only the TraT factor, which 
is involved in serum resistance (Montenegro et al., 1985). This component has been frequently identified in the mammary pathogen strains of E.coli (Kaipainen et al., 2002) and is thought to be involved in the protection of strains against the action of phagocytes. None of the other virulence factors we tried to detect, especially the 12 factors known to be involved in the process of cell adhesion, were observed (data not shown). These results indicate that either $E$. coli $\mathrm{P} 4$ is an environmental strain devoid of any specific virulence properties or genes or that it contains genes yet to be identified as such in a pathogenic E.coli strain. This second hypothesis led us to search for GEI in E. coli $\mathrm{P} 4$, knowing that specific virulence genes are often clustered into GEI (Dozois and Curtiss, 1999).

Foreign acquired DNA sequences are frequently integrated downstream from tRNA genes (Hacker and Kaper, 2000). In this way, numerous GEI have been found and characterized in commensal, intestinal, and extraintestinal pathogenic E. coli strains, revealing novel properties such as the tropism of these strains (Shpigel et al., 2008). Considering these data, as well as the properties of $E$. coli $\mathrm{P} 4$ and the absence of virulence factors commonly found in other pathogenic strains, we decided to seek potential GEI downstream of tRNA genes of this strain. We found that the genomic context of 7 tRNA genes differed from that observed in $E$. coli K-12 MG1655. These altered loci are $\arg W$, asn T, asp $V$, leuX, phe $V$, ser $U$, and thr $W$. They correspond to loci where GEI are frequently detected, as in $E$. coli strain 536 (Oelschlaeger et al., 2002), in the avian pathogenic E. coli Ec222 strain (Parreira and Gyles, 2003), in E. coli RW1473 strain (Jores et al., 2001), and in the nonpathogenic probiotic E. coli strain Nissle 1917 (Grozdanov et al., 2004).

Sequence analysis of $\arg W, \operatorname{asn} T$, leuX, pheV, thr $W$ and $\operatorname{ser} U$ loci showed that their immediate downstream region contained ORF encoding integrases that shared high percentages of similarity with integrases present at the same locus in other strains of E. coli. The presence of integrases downstream of a tRNA gene is a typical feature of GEI, suggesting that GEI are present in the genome of $E$. coli $\mathrm{P} 4$ downstream of these 6 tRNA genes.

The GEI present downstream of $\arg W$ and $\operatorname{ser} U$ were studied in more detail. The complete characterization of the altered $\arg W$ locus revealed typical features of GEI: this GEI is flanked by 23-bp repeats, its size exceeded $10,000 \mathrm{bp}(11,253 \mathrm{bp})$, it contained 2 ORF encoding mobile genetic elements ( 1 putative integrase and 2 putative resolvase), and its $\mathrm{G}+\mathrm{C}$ content $(40.92 \%)$ was clearly different from that of the complete genomes of E. coli (about $50 \%$ ). The GEI located at $\operatorname{ser} U$ was partially sequenced: it contained $7 \mathrm{ORF}$, some of which showed interesting features (see below).

The presence of GEI in E. coli $\mathrm{P} 4$ raises the question about their role in the capacity of the strain to induce mastitis. Answering this question requires us to determine whether these GEI contain specific genes that could be involved in the pathogenicity of $E$. coli $\mathrm{P} 4$. Only the determination of the complete nucleotide sequence of the regions situated downstream from asn T, leuX, phe $V$, ser $U$, and thr $W$ loci would allow us to elucidate their exact genetic content, as was the case for the $\arg W$ locus. The sequence data of the GEI we detected revealed the presence of several genes of interest. First, ORF1 of the serU-GEI encodes a protein similar to a bacteriophage protein implicated in $\mathrm{O}$-antigen conversion. The $\mathrm{O}$-antigen is responsible for the resistance of strains to phagocytosis. Consequently, it could be interesting to determine whether ORF1 is implicated in the conversion of the O-antigen of the strain E. coli P4. The second ORF worth mentioning is ORF4- $\arg W$, which has no homology with any ORF identified to date in any $E$. coli genomes. This ORF encodes a putative protein that contains a Sir2-like conserved domain; that is, a putative protein that catalyzes $\mathrm{NAD}^{+}$-dependent protein/histone deacetylation. Acetylation/deacetylation is one of the important regulation processes of cellular metabolism (Kouzarides, 2000). Sir2 proteins, also known as sirtuins, are found in all eukaryotes and many archaea and prokaryotes and have been shown to regulate gene silencing, DNA repair, metabolic enzymes, and life span (North and Verdin, 2004). To date, sirtuins of yeast and human have been extensively studied. The physiological functions and molecular interactions associated with the other sirtuins, especially the bacterial ones, are still partial. Considering the different roles that could be played by these proteins, it would be interesting to determine whether the protein encoded by the ORF4- $\arg W$ could be involved in the pathogenesis of E. coli $\mathrm{P} 4$ by inducing, for example, transcriptional silencing, a phenomenon shown to play a critical role in bacterial virulence (Dagberg and Uhlin, 1992) or by being involved in a resistance mechanism to the oxidizing stress, which is particularly predominant in the mammary gland during a mastitis (Burvenich et al., 2003). To conclude, the disruption of these genes, followed by studies of the capacity of the mutants of inducing mastitis in animal, could be valuable to determine whether they are involved in the capacity of the strain to provoke mastitis. In addition to the complete characterization of the GEI of E.coli $\mathrm{P} 4$, it would be interesting to extend the study 
we report here to determine the prevalence of DNA sequences identified in this report in strains isolated from mastitis cases

\section{CONCLUSIONS}

In conclusion, this paper reports the presence of GEI in a bovine mastitis pathogen strain of $E$. coli. The first results of sequencing for some loci and the complete characterization of one GEI revealed interesting features that distinguish the mastitis pathogen strain E. coli $\mathrm{P} 4$ from the commensal strain E. coli K-12 MG1655, even though its core genome is close to that of the commensal strain. The presence in the GEI of ORF that are present in other pathogenic strains of $E$. coli showed a connection between the genomes of $E$. coli $\mathrm{P} 4$ and other E. coli pathogenic strains. The systematic search for GEI in other E. coli mastitis pathogens displaying different behaviors during mastitis, their sequencing, and the study of effects of their disruption on the capacity of mutants of inducing mastitis might be a promising way to elucidate the pathogenesis of these strains. Further, such searches might allow us to determine whether the $E$. coli mastitis pathogens constitute a new pathotype in the $E$. coli species; that is, a group of mammopathogenic strains, as suggested by others (Shpigel et al., 2008).

\section{ACKNOWLEDGMENTS}

This work was supported by "Le Ministère de l'Education Nationale, de l'Enseignement Supérieur et de la Recherche." The authors thank Maira Junjua [Unité de Recherche sur l'Animal \& Fonctionalités des Produits Animaux (URAFPA), Equipe ProtéolyseBiofonctionnalité des Protéines et des Peptides, NancyUniversité, Vandoeuvre-lès-Nancy, France] for the reviewing of their manuscript and English corrections. We thank Pascal Rainard [INRA, UR1282 Infectiologie Animale et Santé Publique (IASP), F-37380 Nouzilly, France] for critical reading of the manuscript.

\section{REFERENCES}

Adiri, R. S., U. Gophna, and E. Z. Ron. 2003. Multilocus sequence typing (MLST) of Escherichia coli O78 strains. FEMS Microbiol. Lett. 222:199-203.

Bradley, A. J. 2002. Bovine mastitis: An evolving disease. Vet. J. 164:116-128.

Bradley, A. J., and M. J. Green. 2000. A study of the incidence and significance of intramammary enterobacterial infections acquired during the dry period. J. Dairy Sci. 83:1957-1965.

Bradley, A. J., and M. J. Green. 2001. Adaptation of Escherichia coli to the bovine mammary gland. J. Clin. Microbiol. 39:1845-1849.

Bramley, A. J. 1976. Variations in the susceptibility of lactating and non-lactating bovine udders to infection when infused with Escherichia coli. J. Dairy Res. 43:205-211.
Burvenich, C., V. Van Merris, J. Merhzad, A. Diez-Fraile, and L. Duchateau. 2003. Severity of E. coli mastitis is mainly determined by cow factors. Vet. Res. 34:521-564.

Casadevall, A., and L. A. Pirofski. 2003. The damage-response framework of microbial pathogenesis. Nat. Rev. Microbiol. 1:17-24.

Clermont, O., S. Bonacorsi, and E. Bingen. 2000. Rapid and simple determination of the Escherichia coli phylogenetic group. Appl. Environ. Microbiol. 66:4555-4558.

Dagberg, B., and B. E. Uhlin. 1992. Regulation of virulence associated plasmid genes in enteroinvasive Escherichia coli. J. Bacteriol. 174:7606-7612.

Demuyter, P., P. Leblond, B. Decaris, and J. M. Simonet. 1988. Characterization of two families of spontaneously amplifiable units of DNA in Streptomyces ambofaciens. J. Gen. Microbiol. 134:20012007.

Dezfulian, H., I. Batisson, J. M. Fairbrother, P. C. K. Lau, A. Nassar, G. Szatmari, and J. Harel. 2003. Presence and characterization of extraintestinal pathogenic Escherichia coli virulence genes in F165positive E. coli strains isolated from diseased calves and pigs. J. Clin. Microbiol. 41:1375-1385.

Dobrindt, U., B. Hochhut, U. Hentschel, and J. Hacker. 2004. Genomic islands in pathogenic and environmental microorganisms. Nat. Rev. Microbiol. 2:414-424.

Dogan, B., S. Klaessig, M. Rishniw, R. A. Almeida, S. P. Oliver, K. Simpson, and Y. H. Schukken. 2006. Adherent and invasive Escherichia coli are associated with persistent bovine mastitis. Vet. Microbiol. 116:270-282.

Döpfer, D., R. A. Almeida, T. J. G. M. Lam, H. Nederbragt, S. P. Oliver, and W. Gaastra. 2000. Adhesion and invasion of Escherichia coli from single and recurrent clinical cases of bovine mastitis in vitro. Vet. Microbiol. 74:331-343.

Döpfer, D., H. Nederbragt, R. A. Almeida, and W. Gaastra. 2001. Studies about the mechanism of internalization by mammary epithelial cells of Escherichia coli isolated from persistent bovine mastitis. Vet. Microbiol. 80:285-296.

Dozois, C. M., and R. Curtiss. 1999. Pathogenic diversity of Escherichia coli and the emergence of exotic islands in the gene stream. Vet. Res. 30:157-179.

Dufour, D., N. Jameh, A. Dary, and Y. Le Roux. 2009. Can the mammopathogenic Escherichia coli $\mathrm{P} 4$ strain have a direct role on the caseinolysis of milk observed during bovine mastitis? J. Dairy Sci. 92:1398-1403.

Germon, P., D. Roche, S. Melo, S. Mignon-Grasteau, U. Dobrindt, J. Hacker, C. Schouler, and M. Moulin-Schouleur. 2007. tDNA loci polymorphism and ecto-chromosomal DNA insertion hot-spots are related to the phylogenetic group of E. coli strains. Microbiology 153:826-837.

Ghanbarpour, R., and E. Oswald. 2009. Phylogenetic distribution of virulence genes in Escherichia coli isolated from bovine mastitis in Iran. Res Vet Sci. 88:6-10.

Gonen, E., A. Vallon-Eberhard, S. Elazar, A. Harmelin, O. Brenner, I. Rosenshine, S. Jung, and N. Y. Shpigel. 2007. Toll-like receptor 4 is needed to restrict the invasion of Escherichia coli $\mathrm{P} 4$ into mammary gland epithelial cells in a murine model of acute mastitis. Cell. Microbiol. 9:2826-2838.

Grozdanov, L., C. Raasch, J. Schulze, U. Sonnenborn, G. Gottschalk, J. Hacker, and U. Dobrindt. 2004. Analysis of the genome structure of the non-pathogenic probiotic Escherichia coli strain Nissle 1917. J. Bacteriol. 186:5432-5441.

Hacker, J., and J. B. Kaper. 2000. Pathogenicity islands and the evolution of microbes. Annu. Rev. Microbiol. 54:641-679.

Hejnova, J., D. Pages, C. Rusniok, P. Glaser, P. Sebo, and C. Buchrieser. 2006. Specific regions of genome plasticity and genetic diversity of the commensal Escherichia coli A0 34/86. Int. J. Med. Microbiol. 296:541-546.

Herzer, P. J., S. Inouye, M. Inouye, and T. S. Whittam. 1990. Phylogenetic distribution of branched RNA-linked multicopy singlestranded DNA among natural isolates of Escherichia coli. J. Bacteriol. 172:6175-6181.

Hou, Y. M. 1999. Transfer RNAs and pathogenicity islands. Trends Biochem. Sci. 24:295-298. 
Jores, J., L. Rumer, S. Kiebling, J. B. Kaper, and L. H. Wieler. 2001. A novel locus of enterocyte effacement (LEE) pathogenicity island inserted at phe $\mathrm{V}$ in bovine shiga toxin-producing Escherichia coli O103:H2. FEMS Microbiol. Lett. 204:75-79.

Kaipainen, T., T. Pohjanvirta, N. Y. Shpigel, A. Shwimmer, S. Pyörälä, and S. Pelkonen. 2002. Virulence factors of Escherichia coli isolated from bovine clinical mastitis. Vet. Microbiol. 85:37-46.

Kaper, J. B., J. P. Nataro, and H. L. Mobley. 2004. Pathogenic Escherichia coli. Nat. Rev. Microbiol. 2:123-140.

Kouzarides, T. 2000. Acetylation: A regulatory modification to rival phosphorylation? EMBO J. 19:1176-1179.

Leblond, P., G. Fischer, F. X. Francou, F. Berger, M. Guérineau, and B. Decaris. 1996. The unstable region of Streptomyces ambofaciens includes $210 \mathrm{~kb}$ terminal inverted repeats flanking the extremities of the linear chromosomal DNA. Mol. Microbiol. 19:261-271.

Lehtolainen, T., T. Pohjanvirta, S. Pyorala, and S. Pelkonen. 2003. Association between virulence factors and clinical course of Escherichia coli mastitis. Acta Vet. Scand. 44:203-205.

Long, E., A. V. Capuco, D. L. Wood, T. Sonstegard, G. Tomita, M. J. Paape, and X. Zhao. 2001. Escherichia coli induces apoptosis and proliferation of mammary cells. Cell Death Differ. 8:808-816.

Menzies, F. D., A. W. Gordon, and H. M. Mc Bride. 2003. An epidemiological study of bovine toxic mastitis. Page 1-13 in Proc. Br. Mastitis Conf., Garstang, UK.

Michelutti, I., Y. Le Roux, P. Rainard, B. Poutrel, and F. Laurent. 1999. Sequential changes in milk protein composition after experimental Escherichia coli mastitis. Lait 79:535-549.

Montenegro, M. A., D. Bitter-Suermann, J. K. Timmis, M. E. Agüero, F. C. Cabello, S. C. Sanyal, and K. N. Timmis. 1985. traT gene sequences, serum resistance and pathogenicity-related factors in clinical isolates of Escherichia coli and other gram-negative bacteria. J. Gen. Microbiol. 131:1511-1521.

Nemeth, J., C. A. Muckle, and C. L. Gyles. 1994. In vitro comparison of bovine mastitis and fecal Escherichia coli isolates. Vet. Microbiol. 40:231-238.

North, B. J., and E. Verdin. 2004. Sirtuins: Sir2-related NAD-dependent protein deacetylases. Genome Biol. 5:224.

Oelschlaeger, T. A., U. Dobrindt, and J. Hacker. 2002. Pathogenicity islands of uropathogenic E. coli and the evolution of virulence. Int. J. Antimicrob. Agents 19:517-521.

Parreira, V. R., and C. L. Gyles. 2003. A novel pathogenicity island integrated adjacent to the $t h r \mathrm{~W}$ tRNA gene of avian pathogenic Escherichia coli encodes a vacuolating autotransporter toxin. Infect. Immun. 71:5087-5096.

Picard, B., J. S. Garcia, S. Gouriou, P. Duriez, N. Brahimi, E. Bingen, J. Elion, and E. Denamur. 1999. The link between phylogeny and virulence in Escherichia coli extraintestinal infection. Infect. Immun. 67:546-553.
Rainard, P., and C. Riollet. 2006. Innate immunity of the bovine mammary gland. Vet. Res. 37:369-400.

Reid, S. D., C. Herbelin, A. C. Bumbaugh, R. K. Selander, and T. S. Whittam. 2002. Multilocus sequence typing (MLST) of pathogenic Escherichia coli. http://www.shigatox.net/stec/mlst-new/.

Rumer, L., J. Jores, P. Kirsch, Y. Cavignac, K. Zehmke, and L. H. Wieler. 2003. Dissemination of pheU- and pheV-located genomic islands among enteropathogenic (EPEC) and enterohemorrhagic (EHEC) E. coli and their possible role in the horizontal transfer of the locus of enterocyte effacement (LEE). Int. J. Med. Microbiol. 292:463-475.

Sambrook, J., E. F. Fritsch, and T. Maniatis. 1989. Molecular Cloning: A Laboratory Manual. 2nd ed. Cold Spring Harbor Laboratory Press, Cold Spring Harbor, NY.

Selander, R. K., D. A. Caugant, and T. S. Whittam. 1987. Genetic structure and variation in natural populations of Escherichia coli. Pages 1625-1648 in Escherichia coli and Salmonella typhimurium: Cellular and Molecular Biology. F. C. Neidhart, J. L. Ingraham, K. B. Low, B. Magasanik, M. Schaechter, and H. E. Umbarger, ed. American Society for Microbiology, Washington, DC.

Shpigel, N. Y., S. Elazar, and I. Rosenshine. 2008. Mammary pathogenic Escherichia coli. Curr. Opin. Microbiol. 11:60-65.

Sordillo, L. M., K. Shafer-Weaver, and D. DeRosa. 1997. Immunology of the mammary gland. J. Dairy Sci. 80:1851-1865.

Sordillo, L. M., and K. L. Streicher. 2002. Mammary gland immunity and mastitis susceptibility. J. Mammary Gland Biol. Neoplasia 7:135-146.

Touchon, M., C. Hoede, O. Tenaillon, V. Barbe, S. Baeriswyl, P. Bidet, E. Bingen, S. Bonacorsi, C. Bouchier, O. Bouvet, A. Calteau, H. Chiapello, O. Clermont, S. Cruveiller, A. Danchin, M. Diard, C. Dossat, M. E. Karoui, E. Frapy, L. Garry, J. M. Ghigo, A. M. Gilles, J. Johnson, C. Le Bouguenec, M. Lescat, S. Mangenot, V. Martinez-Jehanne, I. Matic, X. Nassif, S. Oztas, M. A. Petit, C. Pichon, Z. Rouy, C. S. Ruf, D. Schneider, J. Tourret, B. Vacherie, D. Vallenet, C. Medigue, E. P. Rocha, and E. Denamur. 2009. Organised genome dynamics in the Escherichia coli species results in highly diverse adaptive paths. PLoS Genet. 5:e1000344.

Vangroenweghe, F., L. Duchateau, and C. Burvenich. 2004. Moderate inflammatory reaction during experimental Escherichia coli mastitis in primiparous cows. J. Dairy Sci. 87:886-895.

Wenz, J. R., G. M. Barrington, F. B. Garry, K. D. McSweeney, R. P. Dinsmore, G. Goodell, and R. J. Callan. 2001. Bacteremia associated with naturally occurring acute coliform mastitis in dairy cows. J. Am. Vet. Med. Assoc. 219:976-981. 